\title{
MARTA ZAJAC
}

Uniwersytet Śląski w Katowicach

Zuzanna Ginczanka: krytyka, poezja, życie. O tym, jak otwierają się znaki

Zuzanna Ginczanka: criticism, poetry, life. Around semiotic openings

Abstract: The article is an attempt to grasp a feature of the literary and cultural phenomenon of Zuzanna Ginczanka, a Ukrainian-born Polish poetess of the Jewish origin. It refers to 1) biographical elements, 2) their mediation in chosen critical works, as well as 3) the samples of Ginczanka's literary output. The key concept for my investigations is openness (understood mainly as indeterminacy of meaning), which I associate with the intellectual climate of postmodernism, to trace, however, the modalities and variations of openness in Ginczanka's life, criticism and poetry.

Keywords: Ginczanka, openness, postmodernism, Jewishness

Зузанна Гинчанка: критика, поэзия, жизнь. 0 том, как открываются знаки

Резюме: В статье я пытаюсь уловить определенную литературную и культурную черту феномена Зузанны Гинчанки, польской поэтессы еврейского происхождения. Я имею в виду 1) биографические элементы, 2) критические труды, где эти элементы обрабатываются и интерпретируются, а также 3) избранные поэтические произведения. Лейтмотивом моего размышления является понятие открытости (в смысле неопределенности), которое связываю с интеллектуальным климатом постмодернизма, но при этом отслеживаю его различные формы в жизни Гинчанки, в критических трудах ей посвященных и в ее поэзии. Ключевые слова: Гинчанка, открытость, постмодернизм, еврейство

Krytyka, poezja, życie - taką sekwencję obrałam w tytule niniejszego studium, odwracając niejako naturalną kolejność. Albowiem to życie daje przecież początek twórczości, która następnie staje się przedmiotem krytyki literackiej. Ta naturalna kolejność nie jest jednak możliwa do zachowania na poziomie recepcji. Spoglądając na czyjeś życie i twórczość, i pragnąc za ich pośrednictwem dotrzeć do osoby, mamy do dyspozycji materiał literacki i biograficzny, lub odwracając ponownie kolejność, 
biograficzny i literacki, które stają się następnie przedmiotem naszej interpretacji, i w ten sposób przybliżają (lub nie) istotę owej (osobowej) rzeczywistości, którą pragniemy poznać i zgłębić, pochwyceni przez jakieś przypadkowe słowo, frazę i/lub biograficzny detal.

Tak bywa, chociaż oczywiście nie zawsze, ponieważ sama koncepcja odkrywania osoby, konstruowania obrazu czyjejś tożsamości na podstawie językowych tropów jest obecnie często kwestionowana, a czasem poddawana miażdżącej wręcz krytyce. Ale poznawczy głód nie wygasa. Tęsknota za obecnością jest silniejsza niż tejże dekonstrukcja. Mimo skomplikowania i wieloaspektowości współczesnej krytyki literackiej wciąż nie ma pełnej zgody i przyzwolenia na modną i efektowną koncepcję "śmierci autora", sformułowaną przez francuskiego poststrukturalistę (a wcześniej strukturalistę) Rolanda Barthesa.

A piszę o tym przy okazji własnej refleksji nad Zuzanną Ginczanką nieprzypadkowo. Urodzona w Kijowie, dorastająca na Kresach, polska poetka żydowskiego pochodzenia, zamordowana w wieku dwudziestu siedmiu lat przez gestapo, stała się w ostatnich latach przedmiotem bardzo osobistych poszukiwań. Poświęcona Ginczance krytyka literacka sama w sobie przedstawia niejednokrotnie fascynujący materiał badawczy. Można odnieść wrażenie, że życie i twórczość Ginczanki stanowią jednak materię tak atrakcyjną, jak i plastyczną. Rodzą się mity i narracje. A ponieważ poetka nie zdążyła pozostawić własnego komentarza, wiele $z$ jej życia istotnie pozostaje w sferze domysłów, poddane grom naszej wyobraźni.

W niniejszym artykule chcę podać kilka przykładów na to, jak kształtuje się współczesna krytyka Zuzanny Ginczanki. Jakie formy przybierają, i jakie obierają kierunki, wybrane prace krytyczne jej dotyczące. Motywem przewodnim mojej w tym względzie refleksji będzie przy tym szeroko rozumiane, a przez to pojemne, pojęcie otwartości. Zamierzam wskazać, w wybranym przeze mnie kontekście, różne jego modalności i realizacje. Pod koniec swojego wywodu proponuję, jako ilustrację kolejnego otwarcia pojęcia otwartości, własny interpretacyjny trop, odnosząc się do wybranych biograficznych detali i poetyckich przedstawień, które budują także mój obraz Zuzanny Ginczanki, polskiej poetki żydowskiego pochodzenia.

Jednocześnie chcę jeszcze nadmienić (bo nie ma miejsca na szczegółowe omówienie i uzasadnienie tej myśli), że współczesne literaturoznawstwo jest szczególnie wyczulone na wewnętrzną dynamikę znaków i kwestię otwartości procesów 
znaczeniotwórczych. Popularność Ginczanki, postaci i twórczyni niejednoznacznej, może mieć, moim zdaniem, z owym intelektualnym klimatem pewien związek.

\section{Kim jesteś, Zuzanno? Mistyka kobiecości}

„Kiedy powinniśmy zacząć opowiadać?", pyta Jarosław Mikołajewski w książce Cień w cień. Za cieniem Zuzanny Ginczanki. To ważne pytanie. Dla mnie również stało się ono ważne, i to w odniesieniu do tekstu, który zaplanowałam napisać, podobnie jak Mikołajewski, właśnie o Ginczance. „Kiedy powinniśmy zacząć opowiadać? Czy w chwili, kiedy dowiedzieliśmy się już wszystkiego, czy kiedy nie wiemy nic albo prawie nic [...]", pyta dalej Mikołajewski, a ja zastanawiam się, dlaczego przywiązuję aż taką wagę do tego pytania, dlaczego uznaję, że wymaga ono mojego komentarza, dlaczego odbiegam w myślach od Zuzanny Ginczanki, która miała przecież stanowić właściwy przedmiot refleksji, a zamiast tego skupiam się na czyimś komentarzu jej dotyczącym, co się takiego dzieje między mną a tym dziwnym tekstem i pytaniami, które stawia jego autor?

Czy - jako krytyk, jako badaczka literatury - mogę zacząć pisać w chwili, kiedy nie wiem nic albo prawie nic? Tak, nie, zależy. Ale raczej nie. Czy mogę zacząć pisać, mając przed oczyma tylko tekst, który mówi do mnie głosem bliżej nieznanej mi postaci? Czy mogę zacząć pisać, słysząc przede wszystkim tekst, wsłuchując się w to, co się we mnie samej w odpowiedzi na ów tekst dzieje? Tak. Wyłącznie tak. Tak się bowiem wszystko, co ważne w lekturze tekstu, zaczyna. A zatem — tak czy nie? Zależy.

Mikołajewski kończy swoje pytanie następująco: "Kiedy powinniśmy zacząćopowiadać? Czy w chwili, kiedy dowiedzieliśmy się już wszystkiego, czy kiedy nie wiemy nic albo prawie nic, a w tym 'prawie' jest intuicja, że ten ktoś zagęszcza w sobie coś ważnego dla nas, chociaż nie wiemy, ani co to jest, ani co w ogóle dla nas jest ważne?"1. Zawiera zatem w owym ważnym dla siebie pytaniu słowa tak niedookreślone jak — „prawie" czy "coś", a jeśli posłuży się określeniem "coś ważnego", to i tak zaraz przyzna, że nie wie, "co to jest?", gdyż, nie wie, co „w ogóle [...] jest ważne". Dlaczego przypomina mi się Sartre i jego Mdłości? („Z pewnością czegoś się obawiałem, lub coś w tym rodzaju. Gdybym tylko wiedział, czego się boję, byłby to znaczący krok do przodu. Najdziwniejsze jest to, że w żadnym stopniu nie uważam, że oszalałem. Widzę przecież

J. Mikołajewski, Cień w cień. Za cieniem Zuzanny Ginczanki, Wydawnictwo Dowody na istnienie, Warszawa 2019, s. 18. 
jasno, że tak nie jest [...] To znaczy, przynajmniej, chciałbym mieć taką pewność" ${ }^{\prime 2}$. Czy jest to tylko przypadkowe skojarzenie, czy może jeden $z$ istotnych tropów co do materii, z jakiej jest utkana krytyka poezji Zuzanny Ginczanki?

Pytanie, które motywuje poszukiwania Mikołajewskiego, brzmi: kim jesteś Zuzanno? Zapisał je kiedyś, w taki właśnie sposób i „w imieniu Zuzanny", na skrawku gazety, a odpowiedzi udzielił, również w imieniu Zuzanny, na kolejnym wyrwanym z większej całości kawałku papieru. Odpowiedź brzmiała „Jestem tą, która ucieka". Twarz Zuzanny mignęła mu bowiem w chwili, gdy jego badawczemu spojrzeniu wymknęła się, zasłaniając twarz chustą, pewna syryjska kobieta, siedząca pod bramą ośrodka dla uchodźców na Lampedusie ${ }^{3}$. Zobaczył ją jeszcze tylko raz, kiedy na drugi dzień pisała w zeszycie coś, co z kolei zlało się w jego umyśle z Ginczanki poezją. Ta przejmująca, aczkolwiek niekompletna, epifania podsunęła Mikołajewskiemu kolejną myśl, myśl-zjawę, niedookreśloną myśl-widmo (choć w moim odczuciu bardzo trafną i wiernie oddającą nastrój tego przedziwnego związku), myśl o "tajemnicy kobiety"4. (Mistyka kobiecości..., dopowiedziałam już sama). A zatem (jak pięknie pisze Derrida w dziele Ostrogi. Style Nietzschego) myśl jest kobietą, myśl-kobieta jest narzeczoną mężczyzny ${ }^{5}$, kobieta to wieczna ucieczka, myśl, która wciąż nam się wymyka, i w ten sposób uwodzi. Ale Mikołajewski nie lubi zakończeń i nie stawia kropek. Czytamy więc:

\section{Tajemnica kobiety}

Tej kobiety? Kobiety w ogóle? Czy o to właśnie mi chodzi? O tajemnicę kobiety w ogóle? Kobiecości we mnie? Tak czy inaczej, Zuzanna zamieszkała w tajemnicy Syryjki, która właśnie przepłynęła przez morze. Zostawiła siebie gdzieś tam, przeprawiła na tę stronę tylko swój sekret.

Jakoś tak. Nie wiem już, co miałem na myślíi.

Bardzo to wszystko postmodernistyczne ${ }^{7}$ (chociaż po raz kolejny przypomina się też Sartre). Bez większego trudu można

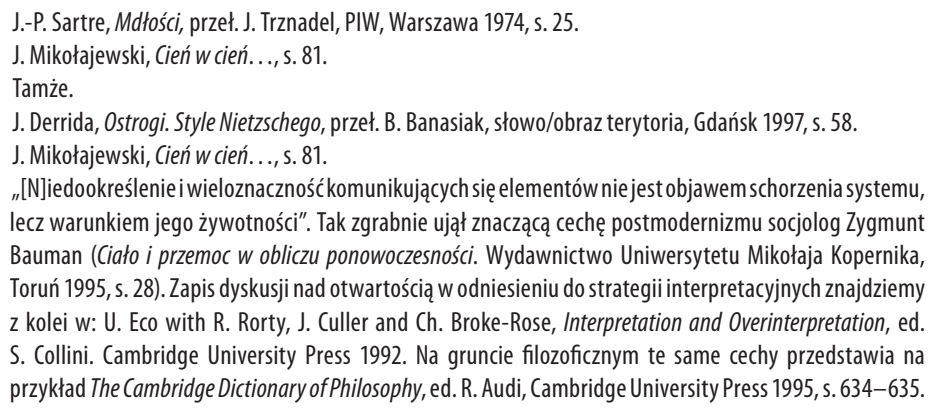


w tym niezwykle osobistym, i niejednokrotnie nad wyraz konkretnym, opisie poszukiwań „tej, która ucieka”, odnaleźć coś niepokojąco bliskiego derridiańskiej grze znaczeń, chłodnej, systemowej zamianie oznaczanych na znaczące. Wybrzmiewa też gorzka rezygnacja w obliczu nieuchronności tegoż, ale i przyzwolenie, aby uwodzicielska moc semiotycznych transakcji przysłoniła, przynajmniej w części, kobietę, która była, żyła i pozostawiła po sobie wiersze świadczące o życiu nader konkretnym, zmysłowym, prawdziwym. Cień w cień. Za cieniem Zuzanny Ginczanki, wyznaje Mikołajewski, to „opowieść o kimś, kto jej [Ginczanki — M.Z.] szuka"8. Ja dodałabym, że również o kimś, kto sam się chowa. „Podczas pracy nad tekstami o Ginczance - poszukiwań jej cienia przez cień, którym sam się czuję, od kiedy tylko czuję cokolwiek"', pisze Mikołajewski na początku przywołanego już rozdziału Sobowtór (w którym Ginczanka użyczyła swej twarzy Syryjce z obozu uchodźców). "Cień, którym sam się czuję, od kiedy tylko czuję cokolwiek" ... To mocne słowa, którym raczej nie do końca możemy ufać, chyba że fraza ta streszcza pogląd, iż każda tożsamość (podobnie jak postmodernistyczna myśl) jest "słaba”, czyli niedookreślona, zmienna, chwiejna. A zatem znowu - postmodernizm. Autor książki Cień w cień nie jest niczyim, nawet swoim własnym cieniem, ukrywa się jednak czasem za misterną fasadą postmodernistycznych tropów i chwytów.

A Ginczanka, dopowiedziałabym jeszcze, dość trywialnie, albowiem na przekór idealizującym i poetyzującym ją tendencjom, jest nie tylko tą, która ucieka, ale także tą, która wraca. Na przykład do osławionego "stolika Gombrowicza” (o którym, i to w chwili, kiedy jego legenda stała się już czymś bardzo żywym i wplecionym w szereg analiz, ktoś - Tadeusz Wittlin — powiedział, że nigdy takiego stolika nie było, że ktoś, ale kto?, ów stolik i jego legendę wymyślił... $\left.{ }^{0}\right)$. Wraca do stolika, który wcześniej opuściła, zrażona mało wyrafinowanymi uwagami i seksualnymi aluzjami dużo starszych i nader nią zainteresowanych mężczyzn. A jednak - wraca. Wydaje się pod pewnymi względami bardzo normalną i bardzo typową młodą kobietą, która afirmuje swoją kobiecość, nawet jeśli nie zawsze z radością przyjmuje komplikacje, które niesie jej wyrazista, wyróżniająca się uroda. Ciekawie brzmi również, kiedy Mikołajewski pisze, że Ginczanka, jeśli spojrzeć na jej twarz utrwaloną na zdjęciach, jest „zbyt pogodna jak na los,

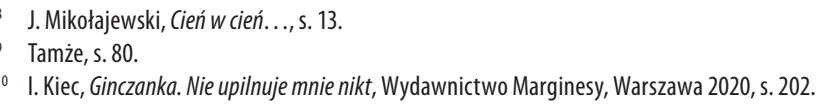


jaki jej zgotowano"11, tropiąc kolejny sekret i tajemnicę cienia, za którym (cień jego cienia) podąża. „Za dużo się uśmiechasz, Zuzanno" zdaje się mówić. W domyśle, za dużo się uśmiechasz, jeśli wziąć pod uwagę twoje tragiczne losy, życie ucięte zbyt szybko i brutalnie, wojenne sponiewieranie, niedokończone wiersze, niewypowiedziane myśli. Ale Zuzanna uśmiecha się przecież wówczas, kiedy jeszcze o tym, co ją spotka, nie wie; uśmiecha się (w istocie, jest to na swój sposób uderzające, bo uśmiecha się tak samo i na każdym prawie zdjęciu), ponieważ jest młoda, piękna, utalentowana, pełna energii i apetytu na życie. Kiedy, w czasie wojny, musiała się ukrywać, kiedy doświadczyła traumy zaszczucia i osaczenia, przestała się też "uśmiechać", twarz, jaką pokazywała światu, znacząco się zmieniła. Jak czytamy w relacjach naocznych świadków, sprawiała wrażenie fizycznie wyniszczonej i psychicznie wyczerpanej. I to również jest normalne. Ale Mikołajewski na taką "normalność", zwyczajność, poetki nie jest gotowy. Kiedy jej twarz mignie mu na taśmie starej kroniki filmowej, twarz uśmiechniętej młodej kobiety, tańczącej tango na dancingu, on odwraca swoją. Jest dla niego jak "duch przyłapany na istnieniu"12. Odrzuca też myśl, że pozowała nago Leonowi Chwistkowi i za nic nie chciałby, jeśli to prawda, owego aktu zobaczyć („Przeraża mnie myśl, że mógłbym kiedyś zobaczyć jej akt. Dla mnie jej piękno jest pięknem [...] pompejańskiej Wiosny, która zrywa kwiat, nie pokazując twarzy"133). Mistyka kobiecości... Ale w jakimś sensie w połączeniu z postmodernistycznym flirtem ze śmiercią, nieobecnością znaczenia, „śmiercią autora”.

\section{(Nie)pewność odnalezionego śladu? Zuzanna niedopowiedziana}

Co ciekawe, w podobnym - postmodernistycznym tonie wypowiada się czasem również Izolda Kiec, redaktorka pierwszych Poezji zebranych Ginczanki i autorka pierwszej jej biografii. I jest ów ton poniekąd zrozumiały. Materiał na jakim pracowała Kiec, przygotowując pierwszą tak szczegółową biografię Zuzanny, owe tony dokumentów, w których mnożą się tabele, plany geodezyjne, szkolne cenzurki, masy papieru, gdzie osobowość $\mathrm{i}$ indywidualność przegrywają z formularzami i wykresami, wszystko to może ostatecznie wyzwolić potrzebę

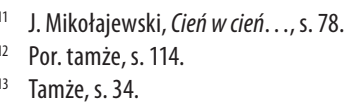


skorygowania wrażenia pewnej zwyczajności, zmusza niemal do powiedzenia, że mimo że urodziła się i umarła, że chodziła do szkoły i spacerowała po prowincjonalnym deptaku, mimo że jej życie jest wpisane w ogólnoludzki schemat, była ostatecznie inna, wyjątkowa i niezwykła.

Być może dlatego właśnie we wstępie do biografii (której podtytuł Nie upilnuje mnie nikt zasługuje na osobne omówienie) Kiec tak bardzo podkreśla niemożność pochwycenia, czy uchwycenia choćby w części, istoty tej, której życie rekonstruuje:

Gdy podczas gromadzenia materiałów do niniejszego wydania biografii Zuzanny Ginczanki raz po raz ogarniała mnie pewność odnalezionego śladu, już po chwili okazywało się, że kolejny dokument, kolejne wspomnienie zawierają inną, nową "prawdę" o autorce. Ujawniają jej nieznaną dotąd twarz ${ }^{14}$;

Czy wobec tak manifestowanej niezależności, domagania się wolności decydowania i wyborów, można uczynić los Zuzanny jednoznacznym? Czy da się go ująć w ramę, zamknąć, opatrzyć etykietą? Czy wypada zabierać poetce prawo do milczenia, intymności i własnych tajemnic? [...] Historia Zuzanny Ginczanki pozostanie niedokończona, a jej osobowość będzie fascynować nierozpoznaniem, niedopowiedzeniem, domysłem ${ }^{15}$.

Zastanawiam się jednak, czy podmiotem tych słów jest rzeczywiście tylko Ginczanka, czy może jest to też wypowiedź o charakterze ogólniejszym. Czy nie wybrzmiewa w niej także niepokój odnoszący się do niejednoznaczności językowych tropów jako takich, intuicja, że język, w jakim wypowiadamy siebie i swoje życie, więcej czasem przesłania niż odsłania? Ale jeśli tak, to przez tego typu zabieg postać Ginczanki, tak starannie budowana, składana, kreślona, ulega odrealnieniu.

Jeszcze inną narrację dotyczącą Ginczanki otwiera interpretacyjna ścieżka Agaty Araszkiewicz. Ona z kolei przypisuje Zuzannie melancholię. Ponieważ ojciec Ginczanki porzucił rodzinę (jak głosiła plotka, próbował szczęścia jako aktor w Hollywood), a matka, z nowym mężem, wyjechała do Hiszpanii, zostawiając jedyną córkę u dziadków, Zuzanna doskonale wpisuje się w opowieść o porzuconym kopciuszku-sierotce, oraz będące tego stanu konsekwencją bolesne uwięzienie w schemacie, określanym za Alice Jouranville "maskaradą kobiecości"16. (Ukochana babcia mogłaby być w tym scenariuszu dobrą wróżką,

\footnotetext{
14 I. Kiec, Ginczanka. Nie upilnuje mnie nikt..., s. 9.

5 Tamże, s. 11.

16 A. Araszkiewicz, Melancholia Zuzanny Ginczanki, „Res Publica nowa”1998, nr 5, s. 55. Na temat "maskarady kobiecości" czytaj więcej: K. Szczuka, Kopciuszek, Frankenstein i inne. Feminizm wobec mitu. Wydawnictwo eFKa, Kraków 2001.
} 
matką chrzestną). Przejrzałam uważnie różne biografie Ginczanki i wciąż mam wątpliwości, czy rodzicielska zdrada miała na jej życie aż tak destrukcyjny wpływ. Wiem, że uśmiech melancholii bywa promienny, ale wiem też, że feministyczne krytyczki lubią przypisywać silnym, twórczym kobietom jakiś wewnętrzny konflikt, pęknięcie, co staje się następnie oskarżeniem wobec patriarchatu tłamszącego ich osobowość (a najczęściej seksualność, i dotyczy to także Ginczanki). Przeobraża się więc Ginczanka w ofiarę. To kolejna już perspektywa, która nie współbrzmi z moim doświadczeniem lektury jej poezji i wglądu w życiowe losy.

\section{W pokoju tłoczyły się meble... Zuzanna Gincburg: (nie)pewny trop?}

Przyznam, że w owej polifonii głosów, gąszczu mistrzowskich analiz, moją uwagę przykuła uderzająca w swej prostocie relacja przyjaciela domu, Izaaka Pawła Gasko:

Dom, w którym Sanka rosła, był duży, dwu-i półpiętrowy, i może w czymś podobny do domów Kafki. Taki dziwny jak jego właścicielka, czcigodna pani Klara Sandberg ${ }^{17}$.

Dlaczego właśnie to zdanie? Z jednej strony, ów krótki opis wyjątkowo silnie przemawia do mojej wyobraźni (nawiązanie do Kafki nie jest zapewne w tym względzie bez znaczenia); z drugiej — przywołuje jedynie wspomnianą do tej pory kwestię żydowskiego pochodzenia poetki. (Klara/Chaja Sandberg to babka Zuzanny, szanowana w Równem właścicielka nie tylko wspomnianego domu, ale i apteki mieszczącej się na jego parterze). Może się wprawdzie wydawać, że trop ów, pytanie o żydowskość Ginczanki, szybko się skończy. Zuzannie, co widać także w jej poezji, daleko było do żydowskiej ortodoksji. Warto jednak powiedzieć na ten temat przynajmniej kilka słów.

Dziadek Ginczanki był jeszcze wierzącym i praktykującym Żydem, rozpaczał na wieść, że jego córka, matka Zuzanny, wiąże się z nie-Żydem ${ }^{18}$. W domu przestrzegano żydowskiego kalendarza, obchodzono religijne święta ${ }^{19}$. Ale Zuzanna dorastała

17 Za: J. Mikołajewski, Cień w cień...., s. 44.

18 Por. „Podobno pomieszania zmysłów dostał właśnie przez to, że matka Sany związała się z ruchem lewicowym", tamże, s. 69.

19 „W rodzinie Sandbergów następował dość powszechnie obserwowany wówczas wśród części Żydów kresowych proces laicyzacji, odchodzenia od surowych religijnych zasad"; „z powodu choroby (psychicznej) męża pani Klary, który mieszkał w wydzielonych dla niego pokojach [... s święta te utraciły 
w środowisku wielokulturowym i w mentalnej wieży Babel ${ }^{20}$. Chodziła do przedszkola z językiem francuskim, gimnazjum wybrała polskie. Jako poetka miała do wyboru cztery języki: rosyjski, jidysz, polski i ukraiński. (Wybrała, jak wiadomo, polski i, jak przejmująco pisze Kiec, była to kolejna życiowa zdrada, której doświadczyła - jej wojenne losy mogły się potoczyć całkiem inaczej, mogła ocaleć, gdyby posługiwała się na przykład mową rosyjską). Z ortodoksyjnymi Żydami w Równem nie odczuwała żadnej więzi. „[P]ostanowiłyście ich nie zauważać. Mieć jak najmniej wspólnego z tym dziwacznym językiem, dziwacznymi imionami i jeszcze bardziej dziwacznymi zwyczajami. Oni żyją swoim, a wy swoim życiem. W chałatach, czarnych kapeluszach albo zwyczajnych czapeczkach, krążą po ulicach", tak odtwarza tę relację Maria Stauber, córka Lusi Gelmont, serdecznej przyjaciółki Zuzanny ${ }^{21}$. Co ciekawe jednak, według innej relacji, Filipa Łobodowskiego, kiedy młoda Zuzanna przybywa do Warszawy, jest wstrząśnięta tym, co widzi w żydowskiej dzielnicy:

jeszcze bardziej przeraziła ją żydowska dzielnica Warszawy [...]. Żydzi Wołyńscy nie nosili chałatów i jarmułek [...] słabo odróżniali się od Polaków i Ukraińców. Była naprawdę przerażona [...] Wychowaną w odmiennych warunkach i otoczeniu raził ten "czarny ląd”, nie poczuwała się do żadnej z nim wspólnoty ${ }^{22}$.

Pojawia się w tym punkcie pewna sprzeczność. Czy po ulicach w Równem krążyli ortodoksyjni Żydzi, Żydzi „w chałatach", Żydzi wyglądający na Żydów (niepodobni więc do niebieskookich Polaków i Ukraińców), czy też nie? Przecież — raczej tak. Dlaczego przyjaciółka Zuzanny, Lusia, miałaby w tym miejscu fantazjować? Ale dlaczego zatem Zuzanna sprawia w Warszawie wrażenie, jakby po raz pierwszy w życiu zobaczyła Żyda w chałacie, jakby do takiego widoku w ogóle nie była przyzwyczajona? I dlaczego, to kolejne pytanie, Równe, ów wielokulturowy tygiel, nie uodporniło jej na taki widok? (Może w Równem owe różnorakie kultury były bardziej ze sobą przemieszane, nie aż tak wyraziste, jak ma to miejsce w stanie izolacji, w specyficznie żydowskiej dzielnicy?)

swój patriarchalny rytuał i doniosłość". I. Kiec, Ginczanka. Nie upilnuje mnie nikt..., s. 231. (Kiec cytuje w tym miejscu ponownie Gasko).

20 „Tu mieszkacie [...] Polak, Żyd, Niemiec, Rusin, Czech, Ormianin. Tu mówicie w różnych językach, piszecie alfabetem łacińskim, bukwami, literą hebrajską i w tej różności [...] żyjecie sobie całkiem spokojnie". M. Stauber, Musisz tam wrócić. Historia przyjaźni Lusi Gelmont i Zuzanny Ginczanki, Wydawnictwo Marginesy, Warszawa 2018, s. 7. Por. J. Mikołajewski, Cień w cień. .., s. 44.

21 M. Stauber, Musisz tam wrócić..., s. 53.

22 I. Kiec, Ginczanka. Nie upilnuje mnie nikt..., s. 232. Kiec cytuje Łobodowskiego. 
Ale - warto sobie uświadomić - żydowskość to coś więcej niż ortodoksja, obrzędy i poczucie przynależności. To również mentalne dziedzictwo, kształtowana przez długie stulecia filozofia życia, takie a nie inne spojrzenie na rzeczywistość ${ }^{23}$. Jeśli taki temat potraktujemy powierzchownie, będą to jedynie spekulacje, fantazje, projekcje, coś, co dopiero trzeba by potwierdzić, ale co potwierdzić byłoby też bardzo trudno. Przyznaję jednak, że bardzo szybko podczas lektury poezji Ginczanki pojawiło się u mnie pewne skojarzenie z szeroko rozumianą właśnie żydowskością. A co bardziej jeszcze znaczące, owo skojarzenie nawiązuje również do plastyczności, otwartości, niedopowiedzeń charakteryzujących koncepcje formułowane w przywołanych przeze mnie krytycznych opracowaniach.

Mówiąc najogólniej, bo nie ma miejsca na bardziej szczegółowe przedstawienia, częścią żydowskiej ortodoksji jest swoista interpretacyjna otwartość. Owa otwartość jest już inherentną cechą samego języka, w jakim spisane zostały żydowskie święte księgi. Hebrajski tekst Tanachu oryginalnie składa się tylko ze spółgłosek, a zatem samo wypełnianie tekstu za pomocą samogłosek otwiera nieskończoną wielość interpretacyjnych ścieżek. A jest to tylko jeden z poziomów. Tak pisze o Torze rabin Marc-Alain Ouaknin: „Nie istnieje sens tekstu, lecz sens, jaki ja mu nadaję. Tekst chce nam coś powiedzieć, ale może powiedzieć coś innego. Jest nieskończenie otwarty. Jest w nim coś nieziemskiego, jakaś 'transcendencja' słów"24. O Talmudzie z kolei dodaje: „Talmud otwiera pole dla wielkiej otwartości umysłu. Wszystko w końcu wolno powiedzieć, wszystko pomyśleć, ale także wszystkiemu zaprzeczyć. Talmud niczego nie ogranicza" ${ }^{25}$. W tym miejscu mógłby powstać pewien, jakkolwiek chwiejny, pomost między pochodzeniem Ginczanki a kierunkiem, jaki obierają wspomniane przeze mnie prace krytyczne dotyczące jej życia i dzieł. Trudno byłoby oczywiście doszukiwać się tu związku logicznego, wcześniej zresztą trzeba by (a nie jest to w tym miejscu, przy formacie mojej refleksji, możliwe) rozważyć kwestię, na ile istotny jest fakt, że sam Jacques Derrida był pochodzenia żydowskiego, studiował przez jakiś czas Talmud, a nawet (podobno) rozważał możliwość studiów rabinicznych. Pozostaje mi jedynie uznać, że Ginczanka, z jakichś względów, silnie przemawia do wyobraźni

${ }^{23}$ Tematykę tę podejmuje i rozwija m.in. S. Quinzio w: Hebrajskie korzenie nowożytności, przeł. M. Bielawski, Wydawnictwo homini, Kraków 2005. Patrz również: A. Lipszyc, Ślad judaizmu w filozofii XX wieku, Wydawnictwo Fundacja im. prof. Mojżesza Schorra, Warszawa 2009.

24 J. Bottero, M.-A. Ouaknin, J. Moingt, Najpiękniejsza historia Boga, przeł. K. Pruski, Cyklady, Warszawa 1998, s. 73.

25 Tamże, s. 74. Patrz również K. Termińska, Studia z hebrajszczyzny biblijnej. Niedoczytanie moje, Wydawnictwo Uniwersytetu Śląskiego, Katowice 2015. 
i wrażliwości postmodernistycznej; pytanie, w jakim stopniu wpływa na to jej (szeroko rozumiana) żydowskość, pozostawiając niemniej otwartym.

Wróćmy jednak do przywołanego konkretu, czyli opisu domu, w którym Zuzanna dorastała, do kolejnej jego odsłony, bo gdzie jak nie tam, w przestrzeni, w której kształtowała się jej codzienność (zapewne w jakimś stopniu na tejże przestrzeni kształtowała się), szukać znaczenia, jakie dla niej samej, organicznie i egzystencjalnie, mogła mieć (tropiona przeze mnie) otwartość? Przyjaciel Ginczanki, także poeta, Jan Śpiewak, tak relacjonuje ich pierwsze spotkanie:

Nie wiedziałem, kim jest Zuzanna Ginczanka, co pisze, jak pisze [...]. Dwa pierwsze wrażenia, jakie odniosłem, pozostały mi na zawsze w pamięci. Pierwsze to dom, w którym mieszkała [...]. Był on piętrowy [...]. W pokojach tłoczyły się meble: staromodne komody, ociężałe fotele, śmiesznie pochylone stoliki i kozetki. Meble zwężały pokój, ciążyły, przytłaczały. Kilka mieszczańskich pokoleń z jakąś konsekwentną chaotycznością musiało je zbierać, aby wytworzyć wreszcie to dziwne nawarstwienie prawie że bezużytecznych przedmiotów ${ }^{26}$.

Dowiadujemy się $w$ ten sposób, że rodzinny dom Zuzanny mógł przytłaczać - ogromem, zagęszczeniem materii, kształtów, nawarstwieniem "bezużytecznych przedmiotów". I jak zauważa Śpiewak, ów ponad dwupiętrowy dom, a w nim gęsto ustawione komody, "ociężałe fotele”, "śmiesznie pochylone stoliki i kozetki”, znacząco kontrastuje ze szczupłą, drobną figurką zamieszkującej ową przestrzeń młodej dziewczyny. Feministyczne pisarki lubią wskazywać przy okazji podobnych opisów na konieczność wyrwania się kobiet z przestrzeni męskiej dominacji, wyjścia poza struktury patriarchalnej opresji. Ten wątek wybrzmiewa też dość donośnie w krytyce poezji Ginczanki ${ }^{27}$. Ale moim zdaniem potrzeba wyzwolenia się z ograniczeń paradygmatu przestrzennego, a jednocześnie $z$ pewnego myślowego schematu, którego ikoną może być rodzinny dom Klary Sandberg, jest problemem uniwersalnym. Z drugiej strony, widzę też w tym pragnieniu coś więcej niż potrzebę dyskursywnej, interpretacyjnej otwartości, o której wcześniej wspominałam.

\section{Nie znam spełnienia swego... Wyjście z labiryntu}

Chciałabym więc na koniec pokazać inną jeszcze formułę otwartości, obecną z kolei w wierszach samej Ginczanki, dostrzec,

\footnotetext{
26 Z. Ginczanka, Poezje zebrane (1931-1944), wstęp i opracowanie. I. Kiec, Wydawnictwo Marginesy, Warszawa 2019, s. 13-14. Podkreślenie moje - M.Z.

27 Por. tamże, s. 13, 15.
} 
jak - w sposób dosłowny i niedosłowny — otwiera się w nich egzystencjalna przestrzeń. Wezmę pod uwagę dwa utwory, Labirynt obłędny z roku 1933 i późniejszy Żar-Ptak (1937). To w nich wyczuwam wspomnianą, odpowiednio, dosłowność i niedosłowność procesu wychodzenia poza przestrzenne i życiowe ograniczenia.

W wierszu Labirynt obłędny przestrzeń egzystencjalna przybiera kształt przestrzeni fizycznej. Mowa o drzwiach i o ścianach. Wyłania się więc obraz pewnej fizyczności, konkretu. Labirynt, przy całej zawiłości swojej struktury, jest ostatecznie formą organizacji przestrzeni. Ta przestrzeń zostaje jednak poszatkowana, jawi się kanciasta i ostra, złowroga w swojej powtarzalności. Każde wyjście, każde odnalezione drzwi, każde miejsce, w którym otwiera się kolejna ściana, jest zarazem wejściem w dokładnie taką samą przestrzeń, przejściem $\mathrm{w}$ miejsce identyczne z tym pozornie pozostawionym za sobą:

Pusty czworokąt w ścianie, drzwi, obłędnie się rozmnaża dokądś dokąd nie spojrzę, rosną drzwi stokrotnie płaskie jak prostokąt ${ }^{28}$.

Drzwi („Pusty czworokąt w ścianie”), choć mnożą się w nieskończoność, niczego nie otwierają i nigdzie nie prowadzą. Ujawniają się poprzez cechy zasadniczo drugorzędne - ramę, rogi, kanty. Przestrzeń labiryntu jest złowrogo monotonna, jednostajna, jednorodna, i w tym sensie zamknięta, nic się tak naprawdę tam nie dzieje („rosną drzwi stokrotnie płaskie jak prostokąt"). Oczekiwane wyjście musi zatem zostać nie tyle odnalezione, co zdobyte poprzez re-organizację życiowej przestrzeni i zmianę sposobu poruszania się w niej:

\section{a jednak chcę na każdy cios w boleści w przód się rwać wieczyście miast czekać w mgle ogłuchłych cisz, aż samo do mnie przyjdzie wyjście ${ }^{29}$.}

Proces ten znajduje moim zdaniem szczególnie głęboki wyraz w kolejnym wierszu Ginczanki tu przywołanym. Żar-Ptak, chociaż bogaty w różnorakie treści, ukazuje przede wszystkim wewnętrzny dynamizm egzystencjalnej przestrzeni. Na pierwszym planie nawiązuje do doświadczeń oraz stanów granicznych. Opisuje spełnienie i śmierć. Bitwy i podróże. Nadzieję i jej utratę. Wreszcie - miłość. A wszystko to w perspektywie młodości. Mogłoby się więc wydawać, że nie ma innego wyjścia, jak tylko zakończyć

28 Tamże, s. 144.

29 Tamże. 
mniej lub bardziej artystycznie udanym - hymnem do miłości i o miłości. Tym bardziej, że spełnienie — dzięki miłości, za pomocą miłości - jest możliwe. Żar-ptak powraca, otwierają się na nowo "miłosne gaje". Tu jednak następuje zaskakujący zwrot — „Panie..." rozlega się niespodziewany szept, jakże nietypowa kobieca suplikacja:

Panie, - powtarzam śpiewnie, - wypróbuj mnie smutkiem, rozpaczą, dnem zatracenia i zguby, lecz szczęściem już nie doświadczaj, nie przetrwam bowiem próby ${ }^{30}$.

Nie doświadczaj mnie szczęściem, błaga młoda kobieta, zatopiona w kontemplacji miłosnych gajów. A kiedy szczęście i spełnienie przychodzą i tak, kiedy mija senność, kiedy wraca utracona wola walki, wciąż jednak towarzyszy temu determinacja, aby nie dać się zniewolić żadnemu pragnieniu, żadnej nadziei, żadnej pokusie spełnienia. Nie dam się zatrzymać, wydaje się mówić poetka, niczego nie chcę uznać w swoim życiu za ostateczne, żadna euforia, ekstaza, błogość, nie powstrzymają mnie od tego, aby eksplorować przestrzeń mojego życia we wszystkich jej wymiarach i aspektach.

Lecz nie ma rzeczy zupełnych — i żadna dlatego rzecz

nie wtrąci mnie w miłość doszczętną, zwątpienie doszczętne ni gniew,

blask piór mnie nie porazi, nie zakołysze mną śpiew,

i skrzydło mnie nie uderzy i nie odrzuci wstecz ${ }^{31}$,

akcentują z niezwykłą siłą ostatnie słowa utworu.

Żydowski filozof i rabin, Abraham Joshua Heschel, stwierdza, że z dwóch egzystencjalnych danych, przestrzeni i czasu, przestrzeń jest nam bliższa, bardziej oswojona. To przestrzeń jest "naturalnym środowiskiem" człowieka. Żyjemy w przestrzeni, czas podporządkowując myśleniu przestrzennemu, i redukując do czwartego jakby wymiaru przestrzeni. Dzieje się to ze szkodą dla życia duchowego. Przestrzeń, i wszystko, co jesteśmy w stanie w niej zgromadzić, zagraża egzystencjalnej swobodzie. Jednym z ważniejszych zadań, jakie przed nami stoją, jest zatem przekroczyć przestrzeń i wejść w czas. Pełnia egzystencjalna oznacza „architekturę czasu”, wznoszenie "pałaców w wieczności”, wieczne trwanie, czyli wieczne - życie ${ }^{32}$.

W wieczności, dopowiedziałabym jeszcze, każda chwila jest tyle samo warta, gdyż tak samo życiodajna. Zamiast pustki -

\footnotetext{
30 Tamże, s. 322.

31 Tamże.

32 Czytaj więcej: A.J. Heschel, Szabat, przeł. H. Halkowski, Esprit, Warszawa 2015.
} 
do wypełnienia, pełnia - do doświadczenia. Byłaby to w moim odczuciu jedna z (doskonalszych) form otwartości, której zapowiedź odnajduję także u Ginczanki.

Nie znam spełnienia swego, jak nie znam śmierci swojej [... $]^{33}$,

deklaruje poetka już w pierwszej linijce wiersza Żar-Ptak.

Niedopowiedziana tożsamość. Niepewne biograficzne tropy. Wielość interpretacyjnych ścieżek. Dosłowne i symboliczne wyjście poza przestrzeń rodzinnego domu. Ale także - zgoda na wszystko, co życie przynosi i czego, nie przynosi, zgoda na jedno, i na drugie, na pełnię i na brak, ponieważ życie jako takie jest już swoją własną pełnią i nie domaga się dopełnienia. Taką nadspodziewanie dojrzałą postawę, wrażliwość, i otwartość, wyczuwam w tajemniczych frazach tropionej przez tak wielu młodziutkiej, żydowskiej poetki. 